\title{
Use of Butea monosperma Extract as Green Corrosion Inhibitor for Mild Steel in $0.5 \mathrm{M} \mathrm{H}_{2} \mathrm{SO}_{4}$
}

\author{
Akhil Saxena, Dwarika Prasad* and Rajesh Haldhar \\ Department of Chemistry, Lovely Professional University, Phagwara, Punjab, India \\ *E-mail: dwarika.maithani@gmail.com
}

doi: $10.20964 / 2017.09 .63$

Received: 11 April 2017 / Accepted: 19 july 2017 / Published: 13 August 2017

The extract of Butea monosperma has been examined to check the inhibitory effectiveness of mild steel corrosion in $0.5 \mathrm{M} \mathrm{H}_{2} \mathrm{SO}_{4}$ by using polarization measurements and EIS technique. The adsorption of Butea monosperma extract on the surface of mild steel has been investigated by using AFM study, SEM study and absorption spectroscopic techniques. This investigation clearly tells us that the extract of Butea monosperma shows very high corrosion inhibition efficiency so it can be used in the form of an excellent inhibitor to protect the metal from corrosion.

Keywords: Butea monosperma, Electrochemical Impedance Spectroscopy, Polarization Measurements, SEM, AFM, weight loss measurements.

\section{FULL TEXT}

(C) 2017 The Authors. Published by ESG (www.electrochemsci.org). This article is an open access article distributed under the terms and conditions of the Creative Commons Attribution license (http://creativecommons.org/licenses/by/4.0/). 